\title{
Pendampingan Pembuatan Business Plan Repositioning Hotel Warna Kedaton Post COVID-19
}

\author{
I Gusti Agung Gede Witarsana1, Ni Putu Diah Prabawati*2 \\ 1,2Program Studi Administrasi Perhotelan, Politeknik Pariwisata Bali \\ Jl. Dharmawangsa, Kampial, Nusa Dua, Telp.(0361) 773537-38 \\ 1 agung.witarsana@ppb.ac.id, ${ }^{2 *}$ prabadiah@ppb.ac.id \\ *Corresponding author
}

\begin{tabular}{l|l|l} 
Received: September,2021 & Accepted: November,2021 & Published: December, 2021 \\
\hline
\end{tabular}

\begin{abstract}
Hotel Warna Kedaton is located in the city of Denpasar, precisely on Jalan Jayagiri Utara number 1 Bali. This hotel has Balinese architecture with basic facilities in the form of 49 guest rooms, supporting facilities such as restaurants, swimming pools and meeting rooms. However, the tight business competition makes this hotel must innovate to be able to compete with its competitors. In addition, the current COVID-19 pandemic has also had an impact on the sustainability of the hotel business. The purpose of this activity is to provide proposals for repositioning as an effort to reach more consumers, compete with competitors, and of course to revive the color of this hotel. This activity is aimed at the owner, employees of the Warna Kedaton Hotel and students of the 2020 Hospitality Administration Study Program $C$ with a total number of 8 participants. This activity is carried out using the mentoring method in the form of lectures, discussions and direct practice. The results of this activity are in the form of making a business plan that emphasizes the proposed repositioning by making changes to the hotel concept, design, marketing, service, as well as hotel organization and management to become a boutique hotel.
\end{abstract}

Keywords: repositioning, business plan, hotel, COVID-19

\begin{abstract}
Abstrak
Hotel Warna Kedaton terletak di kota Denpasar, tepatnya di Jalan Jayagiri Utara nomor 1 Bali. Hotel ini berarsitektur Bali dengan fasilitas dasar berupa 49 kamar tamu, fasilitas penunjang seperti restoran, kolam renang dan ruang pertemuan. Namun persaingan bisnis yang ketat membuat hotel ini harus berinovasi untuk dapat bersaing dengan para pesaingnya. Selain itu, pandemi COVID-19 saat ini juga berdampak pada keberlangsungan bisnis perhotelan. Tujuan dari kegiatan ini adalah untuk memberikan usulan repositioning sebagai upaya untuk menjangkau lebih banyak konsumen, bersaing dengan kompetitor, dan tentunya untuk menghidupkan kembali warna hotel ini. Kegiatan ini ditujukan kepada pemilik, karyawan Hotel Warna Kedaton dan mahasiswa Program Studi C Administrasi Perhotelan Tahun 2020 dengan jumlah peserta 8 orang. Kegiatan ini dilakukan dengan menggunakan metode pendampingan berupa ceramah, diskusi dan praktek langsung. Hasil dari kegiatan ini berupa pembuatan business plan yang menekankan pada usulan
\end{abstract}


Ni Putu Diah Prabawati, I Gusti Agung Gede Witarsana

repositioning dengan melakukan perubahan konsep hotel, desain, pemasaran, pelayanan, serta organisasi dan manajemen hotel menjadi hotel butik.

Kata kunci: repositioning, business plan, hotel, COVID-19

\section{PENDAHULUAN}

Sektor pariwisata sangat terdampak dengan adanya COVID-19, terutama jasa akomodasi. Hotel Warna Kedaton merupakan salah satu hotel primadona pada zamannya. Dengan arsitektur hotel yang bertema budaya Bali ditambah dengan kolam renang dan meeting venue yang cukup luas, Hotel Warna Kedaton merupakan hotel yang sangat berjaya pada tahun 1900-an. Sayangnya, seiring dengan perkembangan zaman, pertumbuhan pariwisata di Bali, dan persaingan yang ketat, keberadaan hotel ini perlahan mulai memudar dan tenggelam dari persaingan hotel-hotel di Bali. Dengan adanya wabah Covid-19 berdampak negatif pada tingkat hunian yang menurun drastis. Tingkat hunian pada awal pandemi COVID-19 sebesar 50\% pada bulan maret 2020 dan kian merosot.

Adanya pandemi ini membuat usaha hotel merugi dan cenderung menutup usahaya. Namun berdasarkan penelitian yang dilakukan oleh Indonesia Hotel \& Restaurant Market Sentiment Survey on the Influence of the COVID-19 Outbreak, Hotel dan Restoran cenderung beranggapan bahwa keadaan pasar akan kembali normal sama seperti keadaan sebelum wabah, bahkan beberapa juga beranggapan bahwa keadaan pasar akan lebih meningkat dari sebelum terdapat wabah, terutama permintaan pasar dari domestic leisure dan MICE. Tentunya dengan melihat kondisi seperti ini, terdapat kemungkinan bahwa occupancy yang ditargetkan tidak akan sesuai rencana. COVID-19 menyebabkan penutupan fasilitas dan juga tempat-tempat umum termasuk hotel. Virus ini juga menyebabkan mobilitas masyarakat terhenti, sehingga untuk saat ini tidak ada pengunjung yang bisa masuk ke Bali kecuali memiliki surat-surat ijin tertentu.

Kementrian Pariwisata dan Ekonomi Kreatif memberikan strategi berdasarkan rencana mitigasi pada bulan Juli-Desember 2020 merupakan bulanbulan fase pemulihan. Pada tahun 2021 pelaku ekonomi atau kegiatan usaha sudah memasuki tahap normalisasi. Melihat rencana pemerintah dan juga market sentimen diatas dapat disimpulkan bahwa pada saat normal nanti kegiatan pariwisata akan berjalan normal bahkan, lebih menguntungkan dibanding tahuntahun sebelumnya. Hotel Warna Kedaton yang memiliki pangsa pasar domestik akan sangat diuntungkan. Pada saat tahap normalisasi berjalan, semua penerbangan baik itu domestik maupun internasional dan juga penyebrangan lewat laut akan dibuka dengan normal.

Lokasi Hotel Warna Kedaton yang terletak di tengah kota Denpasar sebagai pusat bisnis di Bali merupakan suatu keunggulan kompetitif. Selain itu basic arsitektur Hotel Warna Kedaton yang bertema Bali akan menjadi ciri khas yang bias dijual dari hotel ini. Meeting room dengan kapasitas besar yang dimiliki akan menjadi kunci target pasar yang bisa disasar oleh Warna Kedaton. Dan fasilitas penunjang lain seperti restoran dan kolam renang juga akan menambah nilai jual hotel ini.

Berdasarkan permasalah tersebut, tujuan kegiatan ini untuk dapat mempertahankan usaha jasa akomodasi di masa pandemi COVID-19 dan sesudah 
Ni Putu Diah Prabawati, I Gusti Agung Gede Witarsana

COVID-19. Membantu merencanakan business plan yang meliputi perubahan hotel ini dari segi pemasaran, manajemen dan organisasi, keuangan, bahkan juga design interior mapun eksterior hotel. Dengan membuat perencanaan ini diharpkan Hotel Warna Keadaton dapat kembali bangkit. Sasaran yang akan dihasilkan sesuai dengan rencana kegiatan ini yaitu pengelola usaha dapat mempertahankan kondisi usahanya di tengah pandemic COVID-19, pemilik usaha dapat mengantisipasi perubahan pasar pasca COVID-19. Tujuan artikel ini yaitu pembuatan Business plan untuk dijadikan acuan dalam mengambil kebijakan dalam menjalankan hotel post COVID-19. Pelaksanaan kegiatan ini juga sebagai sarana pemenuhan Tri Dharma Perguruan Tinggi pada bidang pengabdian kepada masyarakat.

\section{METODE PELAKSANAAN KEGIATAN}

Kegiatan ini dilakukan dengan 3 (tiga) metode, yaitu berupa kegiatan ceramah, diskusi dan praktek langsung yang dilakukan oleh dosen-dosen Program Studi Administrasi Perhotelan. Pada PKM ini juga melibatkan mahasiswa sebagai bentuk aplikasi pada pembelajaran Perencanaan Jasa Akomodasi (PJA). Mahasiswa dapat mengaplikasikan ilmu yang diperoleh selama pembelajaran dan mengaplikasikan dalam proyek pembuatan business plan. Salah satu hal yang paling penting dalam proses belajar adalah bagaimana ilmu yang mahasiswa dapat di kampus atau institusi dapat terapkan di masyarakat terutama di lingkungan kerja. Kegiatan ini dilaksanakan di Hotel Warna Kedaton. Setelah kegiatan terlaksana, indikator keberhasilannya berupa business plan yang akan digunakan oleh pemilik hotel sebagai acuan dalam pengambilan keputusan.

\section{HASIL DAN PEMBAHASAN}

Pembuatan Business Plan Hotel Warna Kedaton Repositioning Post COVID-19 dibagi menjadi 4 bagian meliputi aspek konsep hotel \& design, pemasaran, manajemen dan keuangan sebagaik berikut:

\subsection{Konsep Hotel dan Design}

Konsep hotel yang akan usung di Hotel Warna Kedaton yang baru adalah boutiqe hotel atau hotel butik dengan standart hotel bintang 3. Hal ini sejalan dengan konsep butik hotel yang dikemukakan Jones et al (2013) menyebutkan bahwa esensi penting yang mencirikan Hotel Butik adalah small size hotel, stylish, dan menawarkan layanan tingkat tinggi. Sehingga dapat diasumsikan bahwa butik hotel identic dengan kepuasan tamu yang tinggi. McIntosh dan Siggs (2005) menemukan layanan yang dipersonalisasi sebagai salah satu karakteristik utama hotel butik dalam studinya.

Hotel Butik merupakan perkembangan baru dalam bisnis hospitaliti khususnya jasa akomodasi yang memiliki konsep baru mengikuti tren modern. Hotel harus mengintegrasikan elemen fungsional dan estetika seperti gaya, tata letak dan arsitektur (Cheng et al, 2016). Butik hotel lekat dengan seni dan budaya, desain dan budaya lokal, situs warisan (heritage), atau layanan dan fasilitas tingkat tinggi (Rogerson, 2010; Aggett, 2007). Khosravi, et all (2014) Temuannya menunjukkan bahwa persepsi tamu hotel terhadap karakteristik hotel butik memiliki empat dimensi, yaitu: layanan khusus, fitur kamar, kenyamanan dan desain hotel. 
Hotel Warna Warna Kedaton terletak di Kota Denpasar yang merupakan pusat bisnis di Bali dan memiliki arsitektur Bali, sehingga akan menjadi lebih menarik jikamengubah Hotel Warna Kedaton yang lama menjadi boutique hotel. Selain itu hotel ini akan diubah menggunakan standart bintang 3 dampak dari persaingan pasar atau hotel sejenis yang ada di sekitar Denpasar.

Penggunaan teknologi juga menjadi salah satu ciri khas butik hotel. Pada hotel Warna Kedaton yang baru, diusulkan untuk menambahkan beberapa aksen teknologi sehingga hotel ini terkesan lebih modern. Penambahan teknologi ini terutama pada bagian kamar tamu seperti penambahan smart lock dan blutooth speaker dan juga penambahan HPL panel di meeting room untuk menunjang kebutuhan meeting di Hotel Warna Kedaton. Aspek interaktif pada hotel ini bukan hanya diperuntukkan kepada tamu hotel, melainkan juga dengan tamu luar yang datang berkunjung. Aspek interaktif diwujudkan dengan menambahkan coffee shop pada Hotel Warna Kedaton yang baru. Coffee shop yang diperuntukkan melayani tamu hotel sekaligus tamu luar yang datang berkunjung dan tentunya akan menjadi unique selling point dari hotel ini.

Design yang diusulkan tidak akan merubah bentuk bangunan utama, namun akan dilakukan renovasi interior, serta penambahan-penambahan fasilitas maupun aksen-aksen tertentu untuk menciptakan suasana butik hotel. Suasana yang ingin ditonjolkan disini adalah suasana butik hotel dengan tema Bali yang modern. Aksen Bali akan terlihat pada bentuk bangunan utama hotel serta pernakpernik dekorasi, sedangkan aksen modern dituangkan pada furniture yang digunakan dan juga fasilitas hotel. Berikut merupakan rancangan design untuk Hotel Warna Kedaton.

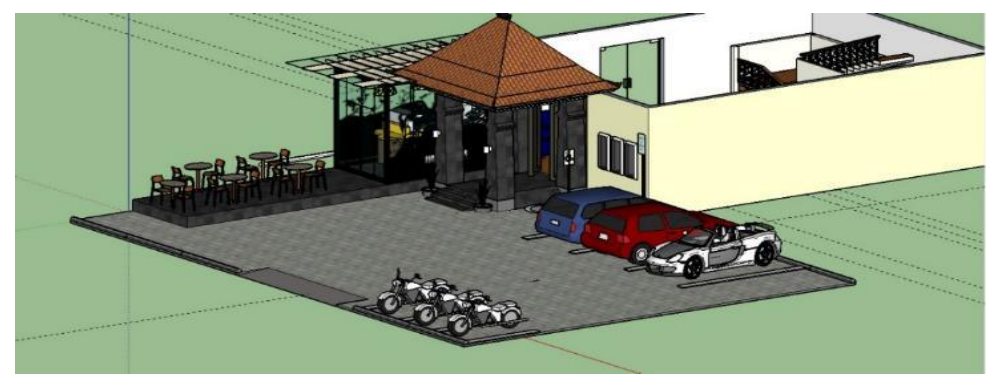

Gambar 1. Tampak Depan Hotel dan Parkir

[Sumber: Businessplan Hotel Warna Kedaton PKM ADH]

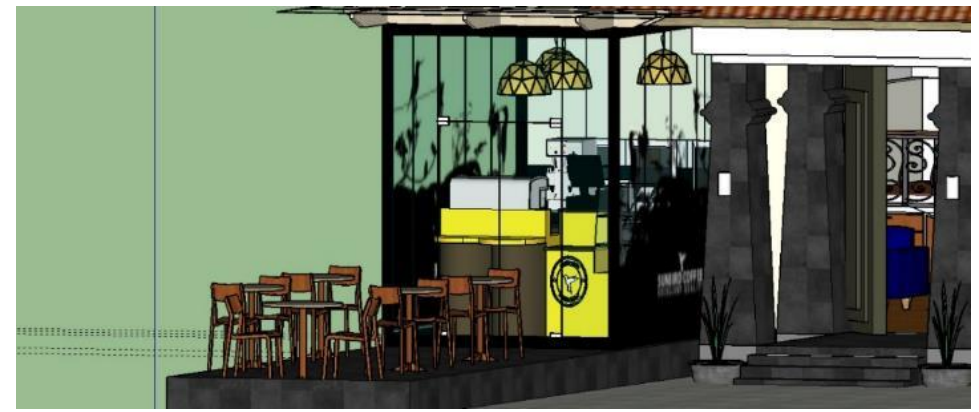

Gambar 2. Coffee Shop

[Sumber: Businessplan Hotel Warna Kedaton PKM ADH] 


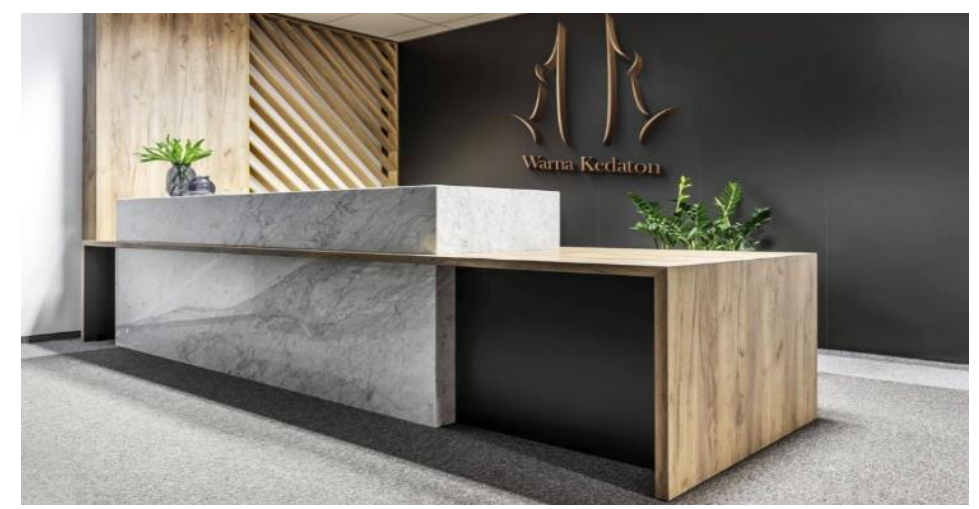

Gambar 3. Lobby

[Sumber: Businessplan Hotel Warna Kedaton PKM ADH]

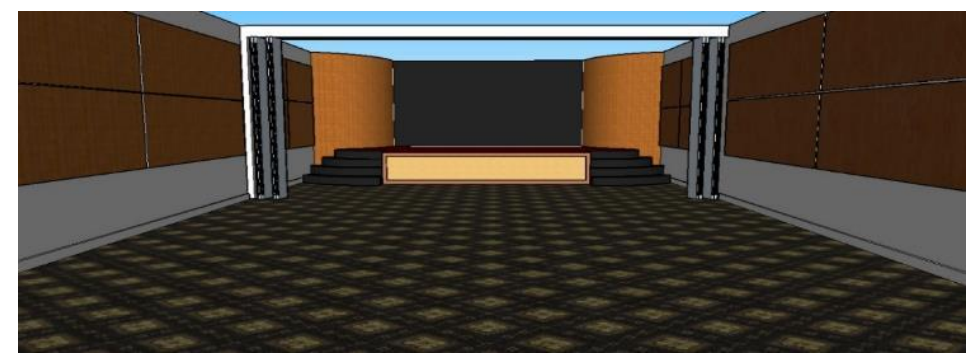

Gambar 4. Meeting room

[Sumber: Businessplan Hotel Warna Kedaton PKM ADH]

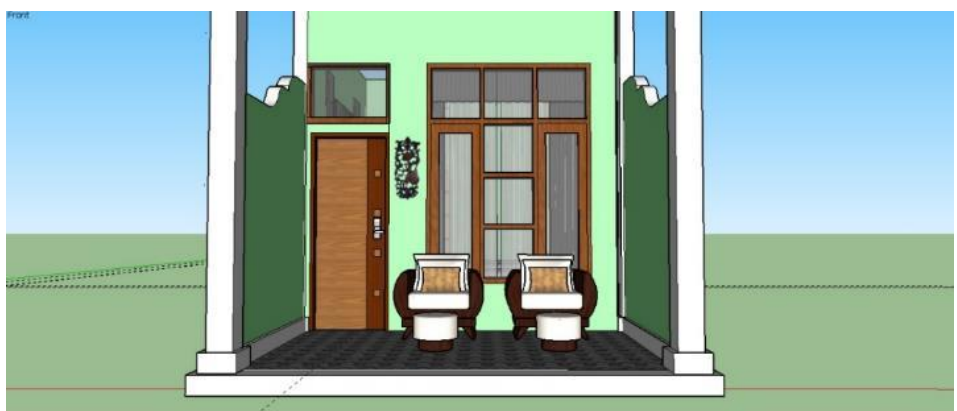

Gambar 5. Tampak Depan Room

[Sumber: Businessplan Hotel Warna Kedaton PKM ADH]

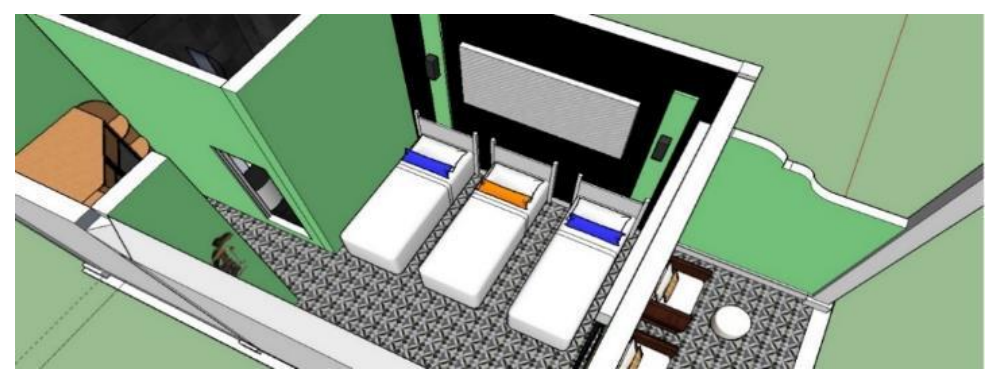

Gambar 6. Layout Bedroom

[Sumber: Businessplan Hotel Warna Kedaton PKM ADH] 


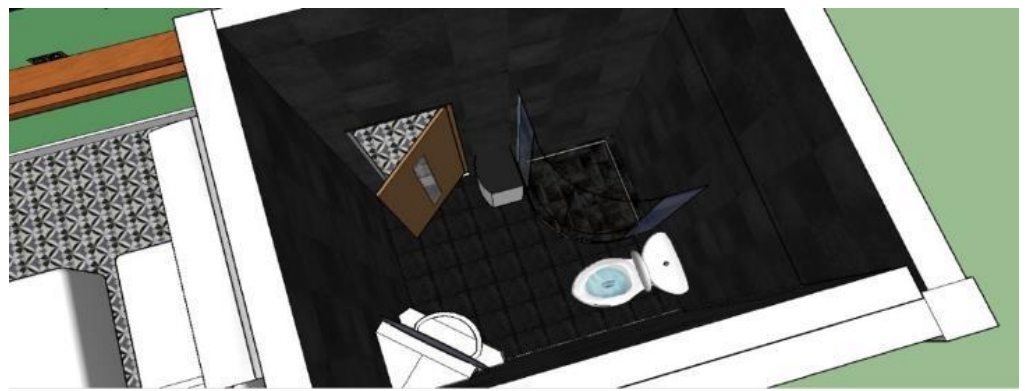

Gambar 7. Layout Bathroom

[Sumber: Businessplan Hotel Warna Kedaton PKM ADH]

\subsection{Pemasaran}

Pemasaran merupakan salah satu aspek yang penting dalam hotel. Dengan konsep pemasaran yang baik diharapkan hotel akan tetap terisi oleh tamu-tamu yang menginap. Segmentasi pasar menurut Kotler (2017) adalah pembagian sebuah pasar menjadi beberapa kelompok pembeli yang berbeda. Segmentasi pada Hotel Warna Kedaton kedepannya akan dikelompokan secara geografis dan kebutuhna tamu. Secara geografis, segmen pasar Hotel Warna Kedaton adalah pasar domestik dan berdasarkan kebutuhan tamu, dibagi menjadi dua yaitu MICE dan leisure. Target pasar ini ditentukan berdasarkan letak dan kondisi geografis Hotel warna Kedaton. Untuk domestic leisure target yang dibidik adalah anak-anak sekolah, mahasiswa, backpaker, dan juga budget traveler. Sedangkan, untuk MICE target yang akan dibidik adalah instansi pemerintah (PNS), mahasiswa, pegawai swasta, dan wirausahawan. Menurut Kotler (2017) positioning adalah desain penawaran perusahaan sehingga menempati posisi dan nilai sesuai yang ditargetkan perusahaan dalam benak pelanggan. Warna Kedaton Hotel menempatkan diri pada posisi persaingan sebagai pengikut pasar (market follower) atau akan melakukan pemasaran dengan strategi "play it safe".

Strategi pemasaran yang digunakan dalam memasarkan Hotel Warna Kedaton yang baru adalah dengan menggunakan marketing mix 7P sebagai berikut:

1) Product. Adapun produk dasar Hotel warna Kedaton meliputi fasilitas lengkap mulai dari suasana kamar yang nyaman, tempat tidur, kamar mandi, lemari pakaian, televisi, AC, Wifi, Meja Rias, wastafel, dan mini speaker. Pada kamar kamar tertentu juga tersedia bathtub, balcony, dan kebun Hotel Warna Kedaton juga dilengkapi dengan kolam renang yang merupakan fasilitas umum dan fasilitas penunjang seperti meeting room dengan kapasitas 100 orang. Selain dari room dan MICE pendapatan Hotel Warna kedaton yang baru juga akan ditambah dari pendapatan coffee shop yang akan dibuat nantinya. Pertimbangan pembuatan coffee shop adalah berdasarkan karakteristik pasar yang rata-rata adalah para pegawai dan mahasiswa yang menyukai tempattempat untuk berkumpul sembari bekerja atau hanya sekedar bermain. Selain itu coffee shop akan dibuka untuk umum sehingga akan menambah pendapatan hotel. Untuk pendapatan coffee shop dari tamu hotel,penjualan yang kami targetkan untuk proyeksi adalah $40 \%$ dari total occupancy hotel. 
Ni Putu Diah Prabawati, I Gusti Agung Gede Witarsana

Sedangkan target penjualan dari tamu luar berdasarkan riset pasar sebelumnya pada saat tahun normalisasi nanti kemungkinan penjualan akan ada di kisaran 10-15 item terjual tiap harinya.

2) Place. Distribution channel yang digunakan dalam strategi pemasaran Hotel Warna Kedaton adalah direct sales terutama untuk pasar MICE dengan cara sales call, website, dan juga pameran. Selain itu penjualan juga akan dilakukan kepada para retailers seperti online dan offline travel agent.

3) Price. Harga yang ditawarkan oleh Hotel Warna Kedaton yang baru adalah IDR 200.000,00++sampai IDR 300.000,00++ sesuai dengan kategori kamar. Harga tersebut termasuk kompetitif jika dibandingkan dengan hotel-hotel sejenisnya. Selain itu terdapat 3 strategi yang nantinya bisa digunakan dalam menentukan harga kamar sesuai dengan kondisi yang terjadi seperti penentuan harga penetrasi, penentuan harga prestis dan ekonomis, dan majemuk.

Tabel 1: Daftar Harga Room Hotel Warna Kedaton 2021-2023

[Sumber: Businessplan Hotel Warna Kedaton PKM ADH]

\begin{tabular}{|c|c|c|c|c|c|}
\hline \multirow{3}{*}{$\begin{array}{l}2021 \\
\text { Room Type }\end{array}$} & \\
\hline & & & Q & & \\
\hline & \multicolumn{2}{|c|}{ Room Rate } & \multirow{2}{*}{$\begin{array}{l}\text { ty } \\
3 \\
3 \\
1\end{array}$} & \multicolumn{2}{|c|}{ Rev per Room Type } \\
\hline Twin Room & IDR & 200.000 & & IDR & 2.600 .000 \\
\hline Triple Room & IDR & 230.000 & $\begin{array}{l}0 \\
2\end{array}$ & IDR & 2.300 .000 \\
\hline Quadruple Room & IDR & 260.000 & 6 & IDR & 6.760 .000 \\
\hline $\begin{array}{l}\text { Revenue per day } \\
\text { (occ } 100 \% \text { ) } \\
\mathbf{2 0 2 2}\end{array}$ & & & & IDR & 11.660 .000 \\
\hline & & & Q & & \\
\hline Room Type & Roor & ate & $\begin{array}{ll}\text { ty } & \end{array}$ & $\operatorname{Rev} 1$ & Room Type \\
\hline Twin Room & IDR & 210.000 & $\begin{array}{l}3 \\
1\end{array}$ & IDR & 2.730 .000 \\
\hline Triple Room & IDR & 241.500 & $\begin{array}{l}0 \\
2\end{array}$ & IDR & 2.415 .000 \\
\hline Quadruple Room & IDR & 273.000 & 6 & IDR & 7.098 .000 \\
\hline $\begin{array}{l}\text { Revenue per day } \\
\text { (occ } 100 \% \text { ) } \\
\mathbf{2 0 2 1}\end{array}$ & & & & IDR & 12.243 .000 \\
\hline Room Type & Roor & ate & $\begin{array}{ll} & Q \\
\text { ty } & \\
& 1\end{array}$ & $\operatorname{Rev} 1$ & Room Type \\
\hline Twin Room & IDR & 220.500 & $\begin{array}{l}3 \\
1\end{array}$ & IDR & 2.866 .500 \\
\hline Triple Room & IDR & 253.575 & $\begin{array}{l}0 \\
2\end{array}$ & IDR & 2.535 .750 \\
\hline Quadruple Room & IDR & 286.650 & 6 & IDR & 7.452 .900 \\
\hline $\begin{array}{l}\text { Revenue per day } \\
\text { (occ } 100 \% \text { ) }\end{array}$ & & & & IDR & 12.855 .150 \\
\hline
\end{tabular}


4) Promotion. Promosi difokuskan terutama melalui media sosial yaitu Instagram. Selain itu terdapat juga website Hotel Warna Kedaton yang akan digunakan sebagai media promosi. Promosi juga akan dilakukan dengan mengikuti pameran atau exhibition.

5) People. Aspek people dalam hotel merupakan faktor penting lainnya dalam people mencakup attitude dan motivation dari karyawan dalam industri jasa. Attitude sangat penting, dapat diaplikasikan dalam berbagai bentuk, seperti penampilan karyawan, suara dalam bicara, body language, ekspresi wajah, dan tutur kata yang semuanya dilakukan dengan ramah serta sopan kepada pengunjung. Sedangkan motivasi karyawan diperlukan untuk mewujudkan penyampaian pesan dan jasa yang ditawarkan pada level yang diekspetasikan. Begitu pula dengan Hotel Warna Kedaton, demi memberikan kualitas pelayanan yang sempurna, pihak manajemen menerapkan konsep untuk membentuk karyawan menjadi orang yang berpribadi/berpendirian teguh, cekatan dan responsive. Penanaman sikap hospitality dan kewenangan dalam menangani complaint. Hotel Warna Kedaton yang baru direncanakan memiliki standart pelayanan yang lebih tinggi dari sebelumnya, sehingga diharapkan dengan standart pelayanan yang baru, keinginan konsumen untuk tinggal di Hotel Warna Kedaton akan meningkat. Aspek yang selanjutnya adalah customer di Hotel Warna Kedaton ini merupakan pengunjung hotel yang ingin menikmati fasilitas hotel dan tamu menginap. Seperti pelancong/orang yang sedang liburan di wisata dekat dengan hotel, pengusaha yang sedang mengadakan pertemuan khusus, EO, dan mahasiswa yang sedang melakukan perjalanan wisata.

6) Process. Proses merupakan seluruh aktivitas kerja di hotel yang memerlukan prosedur. Aktivitas ini dimulai pada saat tamu melakukan pemesanan, sampai pada saat tamu check out. Pembuatan SOP dan job desk kerja. Policy and procedur bagi tamu.

7) Physical Evidence. Hotel Warna Kedaton memiliki design yang menarik dengan konsep butik hotelnya. Letaknya yang strategis ditambah dengan fasilitas penunjang yang dimiliki akan menjadi selling point yang akan ditonjolkan pada hotel ini.

Selain pemasaran dibuat proyeksi penjualan yang akan di capai oleh Hotel Warna Kedaton. Proyeksi ini dibuat berdasarkan kondisi yang terjadi sekarang dan juga asumsi-asumsi dengan data yang asumsi mengacu pada kebijakan pemerintah. Dengan adanya produk dan pelayanan yang terstandart tersebut, strategi yang akan diterapkan dalam pemasaran akan mengarah ke differentiation leadership, dimana hotel ini akan menawarkan kualitas pelayanan dan produk yang berbeda dan dengan harga yang kompetitif.

\subsection{Manajemen}

Berikut merupakan usulan manajemen yang tertuang dalam struktur organisasi yang kami rancangkan pada gambar 8 . 


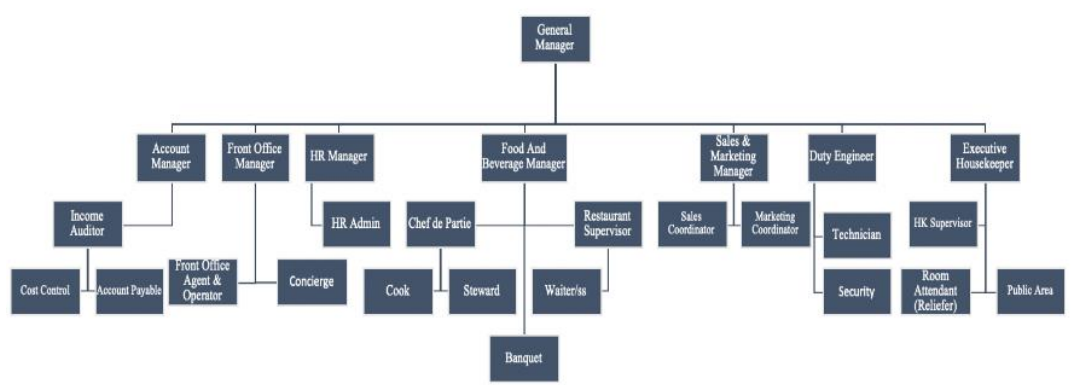

Gambar 8. Pemaparan Materi Pelatihan Oleh Narasumber

[Sumber: Businessplan Hotel Warna Kedaton PKM ADH]

Dari struktur organisasi tersebut jumlah karyawan yang kami butuhkan adalah 53 orang, yang dibagi kedalam empat level manajemen yaitu executive comitee, manager, supervisor, dan staff. Terdapat penambahan jabatan dari struktur organisasi sebelumnya yaitu pada departemen food and beverage dan juga Engineering. Penambahan pada departemen food and beverage adalah untuk membuka kembali restoran yang sudah lama tidak berfungsi. Fungsi dari restoran tersebut selain untuk melayani para tamu untuk makan pagi, juga akan berfungsi untuk melayani tamu MICE. Sedangkan engineering ditambahkan untuk melancarkan oprasional dan security ditambahkan untuk meningkatkan keamanan hotel. Selain itu terdapat beberapa pembagian jabatan yang akan disesuaikan seperti di departemen front office, finance, sales marketing, HR, dan housekeeping.

Tabel 2: Perencanaan Manning Guide

[Sumber: HRD Hotel Warna Kedaton]

\begin{tabular}{|c|c|c|}
\hline Departemen & Jabatan & Jumlah \\
\hline \multirow{4}{*}{ Housekeeping } & Executive Housekeeper & 1 \\
\hline & Housekeeping Supervisor & 1 \\
\hline & Room Attendant (Reliefer) & 6 \\
\hline & Public Area & 3 \\
\hline \multirow{3}{*}{ Kitchen } & Chef de Partie & 2 \\
\hline & Commis & 3 \\
\hline & Steward & 3 \\
\hline \multirow{3}{*}{ F\&B Service } & Restaurant Supervisor & 1 \\
\hline & Waiter/ss & 6 \\
\hline & Banquet & 2 \\
\hline \multirow{3}{*}{ Front Office } & Front Office Manager & 1 \\
\hline & Front Desk Agent + Operator & 3 \\
\hline & Concierge & 2 \\
\hline \multirow{2}{*}{ Engineering } & Duty Engineer & 1 \\
\hline & Technician & 2 \\
\hline \multirow{3}{*}{ Finance } & Account Manager & 1 \\
\hline & Income Auditor & 1 \\
\hline & Cost Control & 1 \\
\hline
\end{tabular}


Ni Putu Diah Prabawati, I Gusti Agung Gede Witarsana

\begin{tabular}{clc}
\hline & Account Payable & 1 \\
& Sales \& Marketing Manager & 1 \\
Sales \& Marketing & Sales Coordinator & 1 \\
& Marketing Coordinator & 1 \\
& Human Resources Manager & 1 \\
Human Resources & Human Resources Admin & 1 \\
& Chief Security & 1 \\
Security & Security & 5 \\
GM & & 1 \\
& TOTAL & 53
\end{tabular}

Pembagian jam kerja adalah 5 hari kerja dan 2 hari libur (5:1) untuk operasional dan back office. Jabatan dalam struktur tersebut dibagi menjadi 4 level manajemen. Untuk jabatan, level tertinggi dimiliki oleh General Manager dan level terendah adalah staff atau karyawan biasa. Setiap level memiliki jumlah gaji masing-masing, yang sudah ditatapkan sebelumnya. Untuk level karyawan yang paling rendah standart upah yang diberikan adalah sesuai UMK (Upah Minimal Kerja) di Kota Denpasar. Sedangkan level berikutnya sampai yang paling tinggi standart gaji yang diberikan adalah UMK dikalikan level manajemen.

\subsection{Keuangan}

Keuangan yang diproyeksikan akan menyesuaikan dengan keadaan pandemi. Dengan adanya COVID-19, penyesuaian harus dilakukan agar nilai investasi dan pengembalian modal dapat dicapai. Maka dari itu, investasi yang diusulkan akan fokus pada renovasi produk utama hotel yaitu kamar atau room, pembuatan coffee shop dan juga renovasi lobby sebagai first impression yang akan dilihat tamu. Selain itu akan ada juga perubahan dalam manning guide yang akan disesuaikan dengan tingkat occupancy hotel.

Adapun perancangan titik impas Break Event Point (BEP) Hotel Warna Kedaton yaitu pada tabel 3 .

Tabel 3: Break event point Warna Kedaton Hotel

[Sumber: Businessplan Hotel Warna Kedaton]

BREAK EVENT POINT WARNA KEDATON HOTEL (NON DISCOUNTED PERIOD)

\begin{tabular}{|c|c|c|c|c|c|c|c|}
\hline \multicolumn{7}{|l|}{ KONSEP } & \multirow{3}{*}{ BEP UNIT/TH } \\
\hline \multicolumn{7}{|c|}{ BEP berdasarkan Fixed Cost, Variable Cost dan Selling Price } & \\
\hline PERIODE -n & & D COST & & BLE COST & SE & PRICE & \\
\hline 1 & IDR & 468.185.221 & IDR & 275.177 .840 & IDR & 200.000 & 1,703 \\
\hline 2 & IDR & 532.100 .834 & IDR & 382.783.636 & IDR & 200.000 & 1,391 \\
\hline 3 & IDR & 565.009 .853 & IDR & $\mathbf{5 1 7 . 7 6 4 . 8 6 1}$ & IDR & 200.000 & 1,092 \\
\hline 4 & IDR & 640.964 .415 & IDR & 546.971 .527 & IDR & 200.000 & 1,172 \\
\hline 5 & IDR & 721.088 .276 & IDR & 592.131 .938 & IDR & 200.000 & 1,218 \\
\hline
\end{tabular}

Berdasarkan tabel perhitungan BEP di atas diperoleh titik impas dengan harga penjualan sebesar Rp. 200.000, maka perusahaan harus dapat menjual sebanyak jumlah dari BEP unit. Jika jumlah penjualan tidak sampai jumlah dari BEP unit, maka tidak akan menutup biaya produksi yang sudah sudah dikeluarkan. 
Pada saat tahun pertama pembukaan hotel dimana rata-rata occupancy yang kami proyeksikan hanya akan berada di angka 20\% jumlah pegawai yang diperlukan untuk kegiatan oprasional hotel adalah 10 orang. Dengan penyesuaian manning guide ini setiap pegawai akan diatih untuk bisa melakukan beberapa kegiatan operasional sehingga pekerjaan akan menjadi lebih efisien dan labor cost dapat ditekan. Penambahan pegawai akan meningkat seiring dengan peningkatan occupancy. Nilai investasi yang diproyeksikan untuk modal awal dan juga biaya renovasi adalah sekitar $\mathrm{Rp} 1.800 .000 .000,00$ dengan profit yang kami prooyeksikan akan meningkat signifikan mulai tahun 2023 dimana pada saat itu kondisi pariwisata di prediksi akan stabil sama seperti sebelum COVID-19.

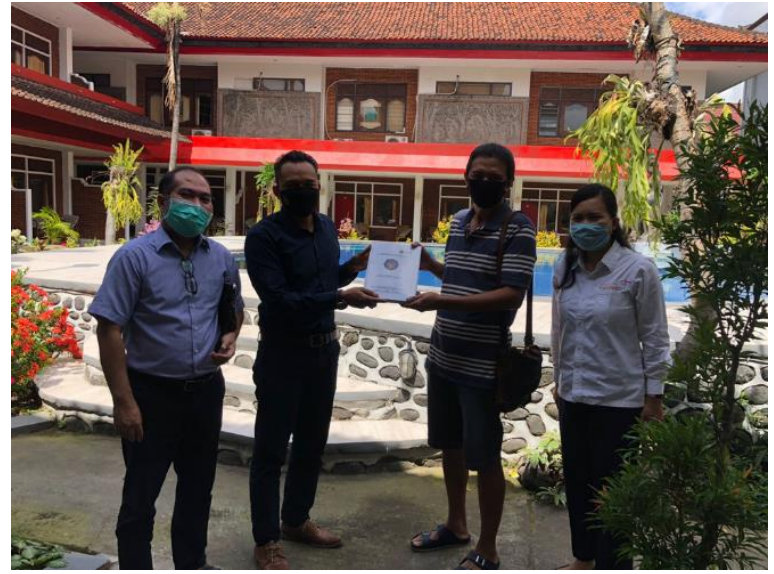

Gambar 9. Penyerahan Business Plan kepada pemilik Hotel Warna Kedaton [Sumber: PKM ADH]

Proses pendampingan yang sudah berjalan dengan kolaborasi antara Dosen Prodi ADH, mahasiswa ADH, pemilik dan karyawan Hotel Warna Kedaton berjalan dengan lancar. Kegiatan pendampingan diakhiri dengan penyerahan dokumen business plan hasil kolaborasi seperti gambar 8 .

\section{KESIMPULAN}

Pendampingan pembuatan business plan sangat diapresiasi oleh pemilik hotel dan karyawan yang menjalankan fungsi manajemen dan operasional. Hotel Warna Kedaton yang baru akan dirubah menjadi butik hotel dengan. Standart minimal hotel bintang 3. Konsep yang akan digunakan dalam Hotel Warna Kedaton yang baru adalah "Modern Balinesse". Desain menimalis, namun terkesan modern dan turut mengusung adat dan kebudayaan Bali akan menjadi fokus dalam pengerjaan arsitektur hotel yang baru. Untuk menunjang pemasukan dan standart hotel, diputuskan untuk membuka kembali restoran hotel ini. Selain itu penambahan coffee shop juga akan dilakukan untu menambah daya tarik hotel ini. Penghasilan kamar dan MICE adalah penghasilan utama dari hotel ini.

Semua bagian oprasional sampai ke manajemen memiliki tugas dan fungsi masing-masing yang diusesuaikan dengan konsep yang akan dibuat. Dengan adanya pandemi COVID-19 maka akan ada beberapa penyesuain yang akan dilakukan baik dari segi investasi, permodalan, dan juga renovasi. Melalui kegiatan ini pemilik dan karyawan hotel dapat mengetahui pembuatan rencana bisnis. Hasil 
Ni Putu Diah Prabawati, I Gusti Agung Gede Witarsana

kegiatan pengabdian kepada masyarakat ini berupa penyerahan hasil final dari business plan.

\section{PERNYATAAN PENGHARGAAN}

Pada kesempatan ini ucapan terima kasih dan penghargaan disampaikan kepada pemilik Hotel Warna Kedaton yaitu Bapak Ida Bagus Alit Tatwa Adnyana yang telah memberikan tempat dan akses data untuk keperluan perancangan business plan. Serta tidak lupa diucapkan penghargaan yang setinggi-tingginya kepada mahasiswa Program Studi ADH C Angkatan 2019 yang dapat mengimplementasikan hasil analisisnya kepada industri.

\section{DAFTAR PUSTAKA}

Aggett, M. (2007), "What has influenced growth in the UK's boutique hotel sector?", International Journal of Contemporary Hospitality Management, Vol.19 No.2, pp.169-17.

Anhar, L., (2001). The Definition of Boutique Hotels. available at: www.Hospitalitynet.org.

Callan, R. J., and Fearon, R. (1997). Town house hotels - an emerging sector, International Journal of Contemporary Hospitality Management 9(4), 168-75. (9) (PDF) Why Tourists are Attracted to Boutique Hotels: Case of Penang Island, Malaysia.. Available from: https://www.researchgate.net/publication/281538354_Why_Tourists_are_A ttracted_to_Boutique_Hotels_Case_of_Penang_Island_Malaysia [accessed Nov 02 2021].

Caterer Search. (2005). Market snapshot: boutique hotels, Caterer and Hotelkeeper. available at: www.caterersearch.com.

Dolnicar, S. and Otter, T. (2003). Which Hotel Attributes Matter? In: Grin, T. \& Harris, R. (eds.).

Jones, D.L., Day, J. and Quadri-Felitti, D. (2013), "Emerging Definitions of Boutique and Lifestyle Hotels: A Delphi Study", Journal of Travel and Tourism Marketing, Vol. 30 No. 7, pp. 715-731.

Khosravi, et all. (2014).Why Tourists are Attracted to Boutique Hotels: Case of Penang Island, Malaysia. Journal of Hospitality \& Tourism, Vol. 12, No. 1, 2014.

Kotler, Philip. (2017). Marketing 4.0: Moving from Traditional to Digital. New Jersey: John Wiley and Son Inc.

Lawson, P. F. (1995). Hotel an Resort: Planning and Design. New York: Architectural Press

McIntosh, A. J., and Siggs, A. (2005). An exploration of the experiential nature of Boutique accommodation. Journal of Travel Research 44, 174-81. (9) (PDF) Why Tourists are Attracted to Boutique Hotels: Case of Penang Island, Malaysia.. Available from: https://www.researchgate.net/publication/281538354_Why_Tourists_are_A ttracted_to_Boutique_Hotels_Case_of_Penang_Island_Malaysia [accessed Nov 02 2021].

Van Hartesvelt, M. (2006). Building a better boutique hotel. Lodging Hospitality 62(14), 32-44. 